\title{
HERBERT SPENCER'S CASE FOR FREE BANKING
}

\author{
BY GEORGE BRAGUES*
}

\begin{abstract}
Though now almost entirely forgotten, Herbert Spencer was among the most widely read thinkers during the late 19th century. As part of his system of synthetic philosophy, Herbert Spencer addressed the topics of money and banking. This philosophic system articulates a concept of justice based on the principle of equal freedom. Invoking this principle, Spencer rejected a government superintended regime of money and banking as unjust. Instead, he morally favored a system of free banking. Spencer also defended this system on economic grounds. His argument is that banks could be self-regulating in their management of the money supply, on the condition that the government limit its activities in the financial sphere to the enforcement of contracts. While Spencer's case is not beyond questioning on philosophic and political grounds, he offers a distinctive and forceful analysis.
\end{abstract}

* Assistant Vice-Provost and Program Head, Business University of Guelph-Humber

Contact: george.bragues@guelphhumber.ca

This "preprint" is the peer-reviewed and accepted typescript of an article that is forthcoming in revised form, after minor editorial changes, in the Journal of the History of Economic Thought (ISSN: 1053-8372), issue TBA. Copyright to the journal's articles is held by the History of Economics Society (HES), whose exclusive licensee and publisher for the journal is Cambridge University Press.

(https://www.cambridge.org/core/journals/journal-of-the-history-of-economic-thought) This preprint may be used only for private research and study and is not to be distributed further.

The preprint may be cited as follows:

Bragues, George. Herbert Spencer's Case for Free Banking. Journal of the History of Economic Thought (forthcoming). Preprint at SocArXiv, osf.io/preprints/socarxiv 


\section{INTRODUCTION}

For most contemporary readers, the idea of exhuming a set of writings on money and banking by Herbert Spencer will appear strange. Indeed, the proposal to revisit any work at all by Spencer will strike many today as a misguided effort. Though there has been some revival of interest in Spencer of late, the nineteenth century British thinker remains largely forgotten. This is despite the fact that he was among the most widely read and discussed figures of his day ${ }^{1}$. While there has been some reconsideration of Spencer's philosophic commitments, he continues to be reproached as an exponent of Social Darwinism (Hofstadter, pp. 31-50; Kennedy, 1978). This is the ideology, ascendant in the late nineteenth and early twentieth centuries, according to which human traits have been determined by the evolutionary struggle for existence. Social Darwinists held that governments ought to reinforce what natural selection has decreed by favoring the reproduction of those individuals best fitted to survive and flourish, while impeding the less fit from passing on their characteristics to future generations.

It is not my purpose here to delve into the question whether Spencer has been correctly interpreted as a Social Darwinist. But tying Spencer to Social Darwinism is arguably both simplistic and unfair (Taylor 2007, pp. 148-150; Leonard 2009). Granted, he sought to develop a moral philosophy predicated on the principles of evolution. Yet similar efforts are made today by a myriad of respectable thinkers invoking the findings of evolutionary psychology (Dawkins 1974; Wright 1994; Ridley 1996; Pinker 2002; Hauser 2006). As we shall see, Spencer

\footnotetext{
${ }^{1}$ Consider the data provided at the Google NGrams (2018), a website which graphs how often certain terms and names are found in Google's database of English language books published between 1500 and 2008. During the late $19^{\text {th }}$ century, Herbert Spencer was more often cited than other intellectual titans of the period, including John Stuart Mill, Auguste Comte, Karl Marx, and Friedrich Nietzsche. Examples of recent interest in Spencer include Francis (2007), Taylor (2007), Offer (2010), Mingardi (2011).
} 
employed a theory of evolution to ground a concept of justice that prioritized the individual's right to freedom over and above any notions of social utility or the common good, including those based on evolutionary fitness.

Look beyond the allegations of Social Darwinism and what one discovers is a stunningly capacious philosopher whose thought continues to be relevant. Spencer devoted the bulk of his intellectual energies to developing a philosophic theory that would explain all dimensions of human affairs --biological, psychological, social, moral, political, and economic. In formulating this theory of everything human -- a system of synthetic philosophy as he called it -- Spencer did not remain at the level of broad generalization. He tried to substantiate his system by applying its conclusions to a wide variety of concrete moral and public policy dilemmas. This launched him into detailed analyses of topics ranging from family, marriage, and children, to education, the administration of justice, and even the delivery of the mail.

Among the topics he addressed in concretizing his grand philosophic project was money and banking. He dealt with these topics in two of his works, one being Chapter 29 of his Social Statics, and the other his essay, "State Tamperings with Money and Banks", originally published in The Westminster Review. Revisiting these works will enrich our understanding of nineteenth century British monetary debates beyond the established narratives pitting bullionists versus anti-bullionists and the banking school against the currency school. For there was also a side that advocated free banking (White 1984; Smith 1990, pp.71-91). Of all the figures on the side of free banking during the nineteenth century, it was Spencer who offered the most thorough case. While Spencer's association with free banking has occasionally been mentioned in the scholarly literature, his arguments for that system has never been analyzed in detail. 
Spencer's thesis, as I shall detail, is that the state's role with respect to money and banking should be limited to the enforcement of contracts. Against the interventionist views that would subsequently emerge as the orthodoxy, Spencer argues that the banking industry is self-adjusting whenever levels of credit issuance and interest rates are freely determined by the negotiations of borrowers and lenders. The condition for this equilibrating process to take place is that governments not interfere with the banks, except through the application of contract law by the justice system.

\section{THE NINETEENTH CENTURY BRITISH DEBATE OVER MONETARY POLICY}

When Spencer ventured into the subject of money and banking, he was not simply working through a list of key institutions and practices to complete his philosophic architectonic. Rather, Spencer waded into a multi-decade controversy about the best way to order Britain's monetary affairs. Having begun at the outset of the nineteenth century, amid the economic turbulence caused by the Napoleonic wars, this battle pitted Britain's leading politicians, economists, and bankers against one another. It included famous thinkers such as David Ricardo and John Stuart Mill in addition to lesser known figures like Henry Thornton, William Boyd, and Robert Torrens ${ }^{2}$. Initially, the debate was between the bullionist and antibullionists, but subsequently the battles lines were redrawn as a contest between the currency and banking schools. Though known by different names, the bullionists and currency school represented a common front in arguing for constraints upon the issuance of money, whereas the

\footnotetext{
${ }^{2}$ For the discussion below, I rely on Viner (1937, pp. 119-289), Mints (1945, pp. 74-100), Fetter (1959), Rothbard ([1995] 2006, pp. 157-274) and Laidler (2000).
} 
anti-bullionists and banking schools together made up an opposing front in maintaining an accommodationist stance.

When Spencer entered this debate in the mid-nineteenth century, it was the banking and currency schools who were chiefly at odds. On its side, the currency school had Lord Overstone, Robert Torrens, and James R. McCulloch. Meanwhile, the banking school featured John Fullarton, Thomas Tooke, and John Stuart Mill. Both sides agreed on maintaining the gold standard that had been re-established in 1821 with the end of the Napoleonic wars. But they differed on whether there should be a rule limiting the bank's issuance of money. The currency school insisted there ought to be such a rule on the grounds that the banks would be liable to overextend credit in the pursuit of interest revenue and thereby fuel an artificial boom that would eventually implode with a series of bank failures. The banking school inveighed against a monetary rule by upholding the real bills doctrine and thus arguing that the money supply can never go beyond the needs of business if lending is limited to the discounting of bills from creditworthy firms. Such prudence, the banking school maintained, would be encouraged by the obligation to exchange species on demand for outstanding notes and deposits. They also stressed the need for flexibility should an economic shock create financial pressures, in which case the banking system must be able to provide liquidity.

With the passage of the Peel Act in 1844, the British government handed a victory to the currency school (Victoriae Reginae [1844] 1892, ch. 32). Named after Robert Peel, then Britain's Prime Minister, the 1844 Act established the Bank of England as the monopoly issuer of notes. It thus became de jure what it had long already been de facto, namely a central bank. At the same time, the Bank of England was restricted in its issuance of notes to the equivalent value of gold in its reserves. Though it was permitted to supply additional notes backed by 
government bonds, this amount was limited to 14 million pounds. The upshot of the Peel Act was an effective $100 \%$ gold reserve requirement for the supply of notes. Crucially, though, this requirement did not extend to bank deposits and credit, in accord with the views of the currency school.

This narrow definition of money proved to be a fatal mistake (Rothbard 2006, pp. 256259). The commercial banks, with the Bank of England acting as an enabler, used this gap in the Peel Act to augment the issuance of credit, and consequently, the amount of deposits. Soon after the Peel Act was passed, this liberal provision of credit fueled a bubble in railroad securities. When this bubble popped in 1847 , and the banks found themselves in difficulty, the Bank of England was forced to rescind the gold reserve requirement on the issuance of notes so that liquidity could be injected into the financial system. A similar suspension was resorted to again in 1857 to manage a new financial crisis that followed yet another credit boom. For the currency school, a legislative victory looked to have been turned into an empirical defeat. Indeed, the Bank of England's multiple suspensions of the gold limitation on note issuance lent great credence to the banking school's contention that monetary policy is best left to discretion rather than the application of rules. For the banking school, a legislative defeat had seemingly turned them into winners.

But there was a third side to this debate. Because none of its core principles subsequently found its way into the conventional wisdom of monetary economics, this position has largely been overlooked by historians. But it represented a force to be reckoned with at the time encompassing Scottish banking elites, the leaders of England's provincial banks, The Economist magazine, as well as a group of thinkers dedicated to the consistent application of 
free market thinking (Fetter 1965, p. 251; White 1984, pp. 65-76). It was this side -- the free banking school -- to which Spencer allied himself when he entered Britain's monetary debates.

\section{THE DEMANDS OF JUSTICE}

To be sure, in Chapter 29 of Social Statics (originally published in 1851 and subsequently revised in 1892), Spencer does lend implicit support to the fundamental contention of the banking school that there should be no legislated restriction on the money supply. Yet he put that contention within a more consistent advocacy of competition for the financial industry, thus placing himself as an exponent of free banking. Spencer did so by treating money and banking not merely as a technical problem of seeking the most efficacious means of advancing public policy objectives - he also dealt with it as a moral concern. To be more precise, he proposed an institutional structure for money and banking that reflected the demands of justice. Other proponents of free banking tended to focus less on moral issues and more on the practical advantages of their vision. To the extent they waded into moral territory, it largely consisted of simple appeals to the ideal of liberty via the contention that people ought to be free to engage in trade, with the realm of money and finance being no exception to that rule (Fetter 1965, 251-252). Spencer was unique among free bankers in providing an elaborate philosophic structure to support his case, applying a fully developed theory of justice.

His most thorough, and methodical, articulation of this theory comes not in Social Statics, but in his The Principles of Ethics, to which we now turn. Committed as he was to the evolutionary approach, Spencer sought the essence of justice by isolating the laws that governed the survival and reproduction of human beings. The first such law, also exhibited in other species, is that all life forms must incur the environmental consequences of the actions 
resulting from the exercise of their physical and mental faculties. It is only by undergoing this response from the environment that the natural selection of traits conducive to survival and reproduction can take place (Spencer 1893, pp. 8-9). Only then is there that "survival of the fittest", a phrase Spencer originally coined, which defines natural evolution. Translated into moral terms, this law becomes the injunction that persons ought to receive the fruits of their actions (pp. 17-18). Against the objection that this is to commit the fallacy of deriving "ought" from "is", Spencer's response is that this law is factually ensconced within the constitution of human beings as an obligatory command. Rather than "ought" being derived from "is", "ought" happens to be contained within the "is". Evidencing this, Spencer observes, is the universal prevalence of maxims like "He has no one to blame for himself" or "he has made his own bed, and now he must lie in it" whenever someone has suffered the painful consequences fitting to wrongful conduct (p. 18). Similar to these are those sayings pertaining to the pleasurable consequences of good conduct: "He got no more than he deserved" or "He has fairly earned his reward" (p.18).

The second law Spencer infers from natural evolution arises among species that develop a group existence. Gregarious species flourish whenever the tendency is for individual members to benefit more by submitting their egoistic impulses to group imperatives than they otherwise could by acting alone in their self-interest. As human beings are among the species where this cooperative logic prevails, there has evolved an inhibition on acts that impede upon the ability of others to pursue their interests (pp. 19-21). Though not always evident where the boundaries are to be drawn, and though its force may be hindered by social practices such as war and slavery, humans have the sense built into their consciousness that other people represent a space 
that one invades at one's peril. When it comes to behavior that affects our fellow humans, we all know deep-down that not everything is permitted.

For Spencer, what nature has evolved in terms of the laws of conduct, reason must refine into principles of morality. With respect to the first law, Spencer observes that an individual cannot receive the consequences of their conduct, unless they are free to act (pp. 2829). To the degree, after all, that people are constrained in their activity, the fruits will not reflect the response typically occasioned by their environment, but rather the contingencies of their confinement. A free individual can experience hard work leading to financial success, whereas a slave cannot. For this reason, Spencer concludes that the first law demanding a connection between conduct and consequences implies the principle of justice according to which each person is at liberty to act as they see fit and assume the resulting costs and benefits. As to the second law's inhibitions upon behavior, Spencer specifies it as the moral principle that nobody is permitted to interfere with the freedom of others to similarly act in the pursuit of their interests. This second law is meant to capture the requirement that individuals constrain their selfish impulses so that the evolutionary benefits of social co-operation can be realized. Basically, the constraint delineated in the second law is equivalent to a recognition that others must not be precluded from exercising the individual liberty specified in the first law. Accordingly, Spencer arrives at his formulation of justice, the principle of equal freedom: "Every man is free to do that which he wills, provided he infringes not the equal freedom of any other man" (p. 46).

How, then, does Spencer apply this principle to explaining the government's role in money and banking? Returning back to Social Statics to answer this question, we find him claiming that a society's proportion of notes to species, whether in the form of coins with 
precious metal content or plain bars, is regulated by the existing levels of trust between individuals (Spencer, 1851, pp. 396-398). In Spencer's time, unlike ours, a bank note represented a promise to pay entitling the holder to a stated amount of cash (i.e., precious metal in one form or another) from the note issuer. Inasmuch as the level of trust in such promises is high, the quantity of notes in circulation will be greater. Having more assurance of being able to exchange their notes for the ultimate form of currency, people will accept the more convenient currency in the form of paper. The opposite will prevail where levels of trust are lower. In that circumstance, people will be more reluctant to accept notes, fearing that they will not be able to exchange them for the metal pieces that always serve as money. People then shift to the use of those metal pieces.

Spencer acknowledged that governments have an interest in promoting the trust that leads to greater use of paper currency. Metal that is simply kept on reserve is dead money, he believed, whereas notes can readily circulate to grease the wheels of commerce. Yet all that governments need do, Spencer insists, in order to cultivate trust is to enforce the contracts implicit in the notes --- namely, the promises to pay the equivalent in species. To go beyond this, whether by restricting who can issue paper money or how much of it can be provided, is to obstruct the right of equal freedom. For suppose that legislation only permits three banks to supply notes in an amount equal to $80 \%$ of their precious metal reserves. The effect of this is to prevent individuals from starting a fourth bank and finding willing takers of their notes. Not only is their freedom compromised, they lack the equal freedom that officials of the three approved banks possess. In turn, the reserve requirement hinders individuals from freely agreeing to accept any notes above the $80 \%$ threshold. They are denied a liberty retained by those already possessing notes. Clearly, this application of the equal freedom principle would 
also forbid the establishment of a central bank, even one whose provision of notes was constrained by a reserve requirement, as was the case in Spencer's time with the Bank of England.

This did not mean that Spencer supported a central bank that was free to issue as many notes as it deemed necessary. By itself, this power did not pose a problem for Spencer. People would still be at liberty to either accept or refuse the central bank's notes in their transactions. They could, in principle, still choose to operate in coins or other forms of metals, or even notes from other countries. The problem is that for the central bank's monopoly over note issuance to be effective, the government has an incentive to pass legal tender laws that render their notes sufficient for the discharge of debts (Spencer 1851, pp. 399-400). Such laws, according to Spencer, are a violation of the principle of equal freedom. This violation is especially glaring in jurisdictions where the law does not allow parties to enter into debt contracts stipulating that repayment be made in gold or a foreign currency. An individual, therefore, willing to lend to another only on the condition that they be paid back in gold, or even some foreign currency, must either grudgingly accept the local government's money for repayment or not issue the loan at all. And if no loan happens to takes place, the potential borrower is prevented from engaging in a transaction to which they would otherwise have consented.

Once tender laws are in place, Spencer argues that the central bank will be able to produce money at will to finance the government's obligations. After all, whomever the government owes money must then accept the central bank's notes. Governments will then be tempted to abandon the convertibility of notes into species, and print money to finance projects that it would prefer not to fund through the imposition of taxes. The result is that people are forced to pay a stealth tax in the form of inflation, a tax to which they did not explicitly consent 
in yet a further violation of the principle of equal freedom. As Spencer warns: "Paper continues to be issued without limit and then comes depreciation; which depreciation is virtually an additional taxation, imposed without the popular consent -- a taxation which, if directly imposed, would make men realize the extravagance of their national expenditure" (p. 400). An understandable objection to Spencer's morally principled approach to money and banking is precisely that it is principled. In essence, Spencer claims to uncover a set of moral intuitions which have been evolutionarily framed into the structure of the human mind. After distilling these intuitions into a fundamental axiom, he then proceeds in the manner of a geometer to deduce the implications for the politico-monetary sphere. Spencer concludes this proof with the superiority of free banking, a regime in which anyone may issue notes subject to their maintaining the trust of those who might accept them. Yet a skeptic may rightly wonder whether the problems of money and banking are susceptible to a deductive solution. Such a skeptic might legitimately raise the question whether we are dealing with an area of public policy where, given the economic alterations and shocks to which money and banking are subject, discretion and pragmatism is especially incumbent.

Spencer has an answer for this skeptic. Granted, he held that the ultimate basis of human knowledge, including those claims successfully made in the sciences, are conclusions drawn from deductive reasoning. As we have seen, his theory of justice, consisting of the principle of equal freedom, is set forth as the result of a series of deductions made from a set of psychological and environmental facts. Nevertheless, Spencer recognized that induction has a role to play in validating knowledge claims. This is because the human mind is liable to error in framing all the necessary inferences and premises by, for example, not following each step in the chain of reasoning or by not breaking that reasoning down to its proper elements (Spencer 
1898, p.409-414). To guard against such errors, Spencer points out that theories arrived at through deduction implicitly contain predictions about events occurring in the empirically verifiable world (Spencer 1868, pp. 30-31). Induction can alert us to mistakes in a deductively generated theory by checking the predictions implied by that theory.

Applying all this to the issue at hand, we must ask: what is the empirical prediction implied by the application of the principle of equal freedom to money and banking? Spencer does not explicitly address this question, but the answer can be deciphered from the approach he takes when he goes on to buttress his case for free banking with inductive arguments. To repeat, the principle of equal freedom is deduced from the requisites of human evolutionary development. As such, the principle of equal freedom is meant to express the norms of justice most consistent with the survival and reproduction of human beings amid the ever-present necessity of adapting to changing environmental circumstances. Consequently, the principle of equal freedom carries the prediction that societies which practice it are best positioned to advance the flourishing of the human species. Translated to the area of money and banking, the expectation of that moral principle is that the laissez faire approach will generate the greatest benefits for individuals and societies. To seal his case, then, Spencer had to substantiate this prediction by showing that free banking will work better than the alternatives in the real world.

\section{SPENCER'S MODEL OF THE MONEY SUPPLY}

In the Social Statics, Spencer pays some heed to the pragmatic consideration of what works. He notes that Scotland, unlike England, had long practiced free banking while experiencing fewer bank failures (pp. 398-399). Even so, Scotland was not in the position that England was in the mid-to-late nineteenth century, namely at the center of the world's financial 
system. This position arguably posed a unique set of challenges, and perhaps responsibilities, for England. Nor can it be so confidently asserted that Scotland was an exemplar of free banking, insofar as banks there depended on the Bank of England for liquidity (Rothbard 1988). While thorough on the application of moral principle, Spencer's case for free banking in Social Statics left much to be empirically desired.

These shortcomings appear to be met in his essay, "State Tamperings with Money and Banks". There is little in the way here of elaboration of moral maxims to particular situations. Instead, Spencer goes into the thickets of monetary policy and the regulation of the financial sector, plodding through the intricacies and nuances of those subjects, while assessing the efficacy of alternative practices and institutions. When the essay was published in 1858, Britain had already been living with the Peel Act for fourteen years. As we have already had occasion to mention, this period saw Britain suffer crises in both 1847 and 1857. Not surprisingly, Spencer devoted attention on how to maintain the stability of the financial system. As the greatest threat to this stability arises during periods of financial stress, Spencer gave considerable thought to the matter of how free banking can manage crises. In doing so, he foreshadowed a point later more famously stated by Walter Bagehot, namely that a welldesigned financial order must be capable of providing ample liquidity in times of difficulty. But he did not think a central bank ought to be entrusted to perform that task. Market forces, Spencer maintained, operating in a competitive banking industry without government interference could alleviate financial stresses. Here again, in addition to the moral framework he summoned, Spencer went beyond his predecessors on the free banking side in developing the case for full competition in the financial sector. Defenders of free banking had tended to avoid the topic of crisis management by emphasizing how their system would prevent financial 
stresses from occurring in the first place given the incentives for probity that would operate on banks. The Scottish experience was cited as supporting evidence (Wilson 1847, 281-285) ${ }^{3}$. Exemplifying this line of argument, John Kinnear, a Scottish writer, insisted that free banking would reduce systemic risk by spreading gold reserves across numerous banks. (Kinnear 1847, 44-45). A prominent activist for free trade, Richard Cobden, argued that market forces would preclude the mistakes to which a discretionary management of the money supply was prone (Cobden cited by Fetter 1965, p. 176).

To demonstrate how free banking can manage financial crises, Spencer articulates a model of the money supply using a binary classificatory scheme. As such, he distinguishes between immediate and future forms of payment as dual constituents of the money supply (Spencer [1891] 1996, pp. 326-330). An immediate form of payment would be coins and notes. What makes these immediate forms of payment is that once coins and notes are provided in exchange for goods and services, the transaction between the parties is essentially complete. Their relationship, at least with respect to the transaction, ceases; their obligations to one another are canceled. This is not the case with future promises to pay. Included in this category would be the various kinds of bank deposits, bills of exchange, promissory notes, treasury bills, commercial paper, and bonds. With all these instruments, there is a web of relationships, with attendant obligations, which persists. For example, after receiving a Treasury bill in exchange

\footnotetext{
${ }^{3}$ It should be noted that John Wilson, founder of The Economist and an advocate of free markets, did not ultimately counsel that Britain adopt free banking. While he viewed that system as theoretically the best, he thought it more practicable, given the public's basic confidence in the status quo regime, to maintain a state bank issuing notes, albeit with tighter supervision by Parliament.
} 
for money, the holder maintains a relationship with the government as a person to whom the latter owes a specific amount of money at a designated point in the future. ${ }^{4}$

Spencer's emphasis upon promises in defining money does have the merit of placing the issue of confidence at the forefront. This is arguably where it belongs since confidence in other people's ability to fulfill their promises plays a crucial role in the operation of the financial system. We need only recall how a lack of confidence in the safety of bank deposits during the Great Depression contributed to a collapse in the money supply (Friedman and Schwartz 1963, pp. 332-333). More recently, in the throes of the 2008 crisis, financial institutions were forced to pay elevated rates of interest for short-term funding in the inter-bank market as all the participants in that trading arena became less trusting of one another (Cornett, $\mathrm{McNutt}$, et al 2010). As these historical events attest, both the quantity of money, and the price paid to borrow it, is a function of the confidence that people have in the paper-based promises, and now also electronic notations, issued within the financial system as money is created.

Spencer elaborates this insight by conceiving the money supply as a constantly adjusting shifting proportion between immediate and future forms of payment. Determining this proportion at any given place and time are two kinds of confidence: first, the confidence that people have in each other's promises, namely trust; and secondly, the confidence that people

\footnotetext{
${ }^{4}$ This definitional schema for money looks rather odd against the present understanding. The U.S. Federal Reserve (Fed) and the European Central Bank (ECB) define money in terms of the objects that are always accepted for payments, cash in other words, or in relation to assets that can be readily translated into cash. It follows from this conception that there can be narrower and broader measures of money depending on how proximate with respect to liquidity the assets in question are to the objects accepted for payment. Thus, M1 is a narrow measure in that it is limited to currency (notes and coins) in circulation as well as demand deposits, M2 is somewhat broader in that it also includes short-term time deposits, while M3 is broader still by adding long-term time deposits and money market securities (Federal Reserve System, 2018 \& European Central Bank, 2018). Instead of using cash and liquidity as the definitional criteria, Spencer uses the factor of time to payment as the way to comprehend monetary phenomena.
} 
have in the ultimate success of commercial ventures given the conditions in the relevant industry or in the general economy.

The first factor reflects the prevailing level of honesty in society. This will differ from one society to the next, reflecting its historical evolution, culture and institutions. Using conceptual tools from contemporary social science, one could elaborate upon Spencer's point here by reference to the distinction that has been identified between high-trust and low-trust societies (Fukuyama 1995). Spencer posits that high levels of honesty lead to a higher proportion of the money supply consisting of future promises to pay since people will have greater confidence in non-cash forms of money being translatable to cash. On the contrary, where honesty levels are low, cash will be preferred to non-cash forms of money since one cannot be sure that other parties will fulfill their obligations. As such, the Spencerian hypothesis would be that high-trust societies will have larger proportions of future promises to pay, whereas low-trust societies will be more reliant on immediate modes of payment. Irrespective of the society, however, the role played by trust in determining the structure of the money supply will only vary in accord with changes in the culture and institutions.

Consequently, the second dimension of trust -- reflecting the hope and anxiety with which current industrial and economic conditions are viewed - ends up being the more variable factor. For as anyone who has followed the stock market knows, investor and business sentiment about the economy can quickly change. From one week to the next, giddy optimism can turn into dour pessimism and vice-versa. Spencer employs the concept of prudence to comprehend these opposite poles. A high degree of optimism represents a state where prudence is relatively lacking in financial decisions. By contrast, an elevated level of pessimism implies a situation where the caution inherent to prudence becomes extreme. To the extent that prudence 
is lower in optimistic phases, the ratio of immediate to future forms of payments in the money supply falls. That is, individuals become more willing to accept non-cash forms of money with longer maturities in lieu of cash. People are then confident that the parties issuing them future promises will ultimately keep their word, not so much because they trust their characters, but because they think economic conditions will enable them to pay. Of course, the situation is reversed where the level of prudence rises with the fading of optimistic sentiment and the onset of pessimism. In this phase, the willingness to accept non-cash forms of money falls relative to cash, as people no longer believe that counterparties will have the economic wherewithal to fulfill their promises.

It is important to point out that, in Spencer's model, the proportion of immediate to future forms of payment is not all that changes. Inasmuch as future forms of payment tend to constitute a much larger amount of the money supply than cash, a change in the proportion between the two will impact over-all levels of liquidity. More precisely, an increase in the ratio of immediate to future forms of payments leads to a lower money supply, while a decrease in that ratio leads to a higher money supply. What all this means is that, for Spencer, prudence varies inversely with money supply. The money supply will fall, the greater the prudence, or caution, that is exercised by actors in the financial system. Conversely, the money supply will grow, the lower the prudence, or caution, that animates the financial system.

To complete Spencer's model, there are two additional elements to include. One is the variable of business needs (Spencer [1891] 1996, p. 344). This makes itself felt in the demand for short-term credit to meet those operating requirements not attributable to the fluctuations of sentiment between pessimism and optimism. These business needs might be owing to seasonal factors, shifts in the labor market, international market conditions, changes in input prices, and 
the like. To the extent that business needs give rise to more requests for short-term credit, the demand for future forms of payment increases. The result, everything else being equal, is a fall in the ratio of intermediate to future forms of payment in the money supply, and a consequent increase in total amount of money. Not surprisingly, this increased demand must affect interest rates. Since the extension of credit carries with it a promise to pay, the price of credit will vary with the demand and supply of that part of the money stock that consists of future forms of payment. Hence, increased business needs for short-term credit, everything else remaining equal, gives way to a rise in the money supply, as does higher levels of honesty and a reduction of prudence. Conversely, decreases in business needs for short-term credit, lower levels of honesty, and higher degrees of prudence are factors that diminish the money supply by raising the ratio of intermediate to future forms of payment.

An important caveat is that Spencer's model of the money supply assumes that the government role is limited to the enforcement of contracts. To comprehend today's world, in which central banks superintend the issuance of an inconvertible currency, Spencer's model would have to be adapted to explain the nature of financial panics. Instead of the intermediate form of payment being precious metal, it would consist of the coins and notes issued by the central bank. Still, this status of the coins and notes would come to depend on the degree of confidence held by economic actors that the central bank will not abuse its authority to produce excess money. Any reduction in such confidence will lead to other monies being preferred as immediate forms of payment. In other words, the trust factor in Spencer's model of the money supply continues to be relevant. This factor turns out to be crucial for his case that the determination of money can be largely left to market forces - even during the biggest test for a financial system, a crisis. 


\section{MARKET-BASED CRISIS MANAGEMENT}

How, then, does Spencer's conception of the money supply illuminate the ways in which an unregulated banking sector can overcome financial stresses? When we speak of these stresses, Spencer points out, what we mean is that a significant number of borrowers within the financial system suddenly find themselves challenged to fulfill their immediate debt obligations. This could arise because the revenues of many borrowers suffer a precipitous drop all at the same time. Events that could bring this about include a drought, a natural disaster, the initiation of a war, the imposition of tariffs by a foreign nation, the abrupt collapse of a key export market, or some other analogous economic shock (p. 329). Similarly, an economic shock could simultaneously reduce the value of assets across a wide array of firms, making it more difficult for them to pledge the collateral necessary to obtain new funding to repay maturing debt.

In whatever manner this crunch comes about, the banks themselves come under pressure. After all, an inability to collect on the loans they have extended implies a deterioration in the value of their own assets. Meanwhile, commercial banks operate on a highly leveraged basis, not having sufficient reserves on hand to satisfy the demands of its depositors were many of them at once to withdraw their money. This leverage is greater still to the extent that banks have limited equity on their balance sheets. Under these circumstances, banks will be looking to call in existing loans and reduce their existing loan book with a view to shoring up their reserves. That in turn makes it difficult for a wider swathe of firms, beyond those originally under stress, to obtain necessary funding. These additional firms may then find it difficult to 
fulfill their immediate debt obligations, spreading the problem further and putting added pressure on the banks.

The threat is that anyone fortunate enough to have immediate forms of payment, namely cash, in their possession will hoard it to ensure they have enough liquidity to meet their obligations. But cash that suddenly is not spent or lent ultimately means less revenues for others, who then must retrench their operations and sell their assets to repay liabilities. With this dynamic in place, economic activity collapses and wealth is destroyed. A financial crisis becomes an economic calamity.

For the case to be made that market forces can be relied upon to prevent this downward spiral from occurring, a plausible account must be given of how hoarding will fail to take hold without government action. Market forces cannot prevent economic shocks from buffeting the financial system in the first place. If markets offer a solution, it will be owing to their capacity to absorb shocks and bring about the necessary adjustments. This is precisely what Spencer endeavors to show by telling a story of how the banks would confront a jolt to their operations (pp. 331-334).

That story can be encapsulated as follows: when the crunch begins to reverberate among the banks and a cluster of entities are unable to make their debt payments, a fair number of those borrowers can be expected to have solid long-term assets on their balance sheets. In other words, there will be individuals and firms that will be squeezed for liquidity, but nevertheless solvent. They will have the option of seeking an extension on their short-term debt by pledging their long-term assets as collateral. They would, moreover, have strong incentives to take this option, since it avoids the prospect of default and, therewith, bankruptcy. As the many still solvent entities proceed to seek debt extensions, the demand for credit increases. The 
consequence of this is a rise in interest rates. These higher rates, promising greater revenue for lenders, will induce banks to agree to the debt extension requests of those individuals and firms able to offer good long-term assets as collateral. Spencer describes the process as a reprieve that the financial system extends to firms by enabling a switch in the source of their financing from floating to fixed assets:

... such of these claims [on company assets] as the deficient floating capital does not suffice to meet, are replaced by claims on fixed capital. The memoranda of claims which should have disappeared by liquidation, reappear in a new form; and the quantity of paper-currency is increased ... This issuing of securities for future payment when there does not exist the wherewith for immediate payment, is a means of mitigating national disasters. The process amounts to a postponement of trading engagements which cannot at once be met. (Ibid. p. $329 \&$ p. 331)

Once it comes to be widely recognized that loans can be readily obtained, any hoarding of cash induced by the initial stresses comes to an end. For why preserve cash when it generates no return and it can be gotten from the bank as the necessity arises? To buttress this point, Spencer notes that when liquidity was supplied during the 1793 and 1825 crises, "the mere consciousness that loans could be had, itself prevented them from being required" (p. 340). With the hoarding of cash thus contained, the decisive factor that powers the downward spiral of a financial crisis is neutralized. Calm is restored. Afterwards, upon the normalization of economic conditions, firms endeavor to retire their debt as soon as possible. Their aim here is to 
avoid continue paying the high interest rates that they contracted in order to obtain much needed liquidity. "Hence, as fast as prosperity returns", Spencer notes, "he gladly escapes this heavy tax by repaying the loan" (p. 332). That debt being paid, the balance sheets of firms return to more sustainable debt to equity ratios, with long-term assets no longer being pledged against short-term liabilities. The crisis is resolved upon a stable foundation.

When we interpret this story through the lens of Spencer's model of the money supply, what happens is that the self-equilibrating process comes about by shifts in the proportion of immediate to future forms of payment.

\section{Figure 1: The Monetary Progression of a Crisis}

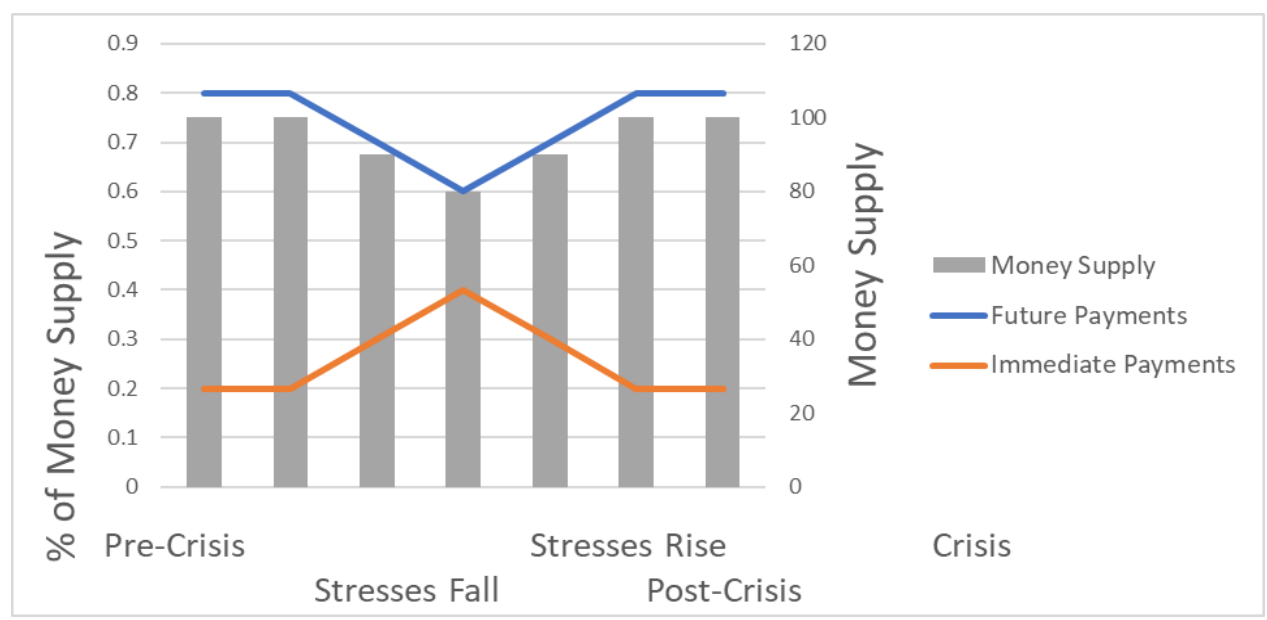

As depicted in Figure 1 above, the ratio of immediate to future forms of payments increases during the initial crunch phase. Reflecting this is the unwillingness of the players in the financial system to accept short-term debt instruments along with the resulting chase for cash. Because future forms of payment constitute the larger portion of the money supply, this latter variable falls as well. Insofar as this induces a rise in interest rates, the incentives change 
for the players such that the ratio of intermediate to future forms of payments begins to fall at the height of the crisis. In this way, the ratio is eventually brought back to pre-crisis levels at the same time as the money supply rises.

Aside from all this not requiring government action, an added benefit of the laissez faire strategy for Spencer is that the economic structure is put back on a sound footing. The market cure is not a temporary fix in which elements are introduced, or left untouched, that bode ill for the future. For one thing, it is only those firms that are solvent, those still with promising longterm prospects, which are saved. On the other hand, companies that made poor investments with the funding provided to them by the financial system, companies whose projections of future profits prove illusory once funding becomes scarce -- their long-term assets are fatally impaired. With nothing to offer as collateral, such firms go bankrupt. "Under a free system", Spencer observes, "the good will be sifted from the bad" (p. 347). Capital that turns out to have been misallocated to them is now allowed to shift to more promising projects. As Spencer argues, "there will really occur that purification of the mercantile world which many think can be effected only by some Act-of-Parliament ordeal" (Ibid., p. 347). By contrast, when a central bank intervenes in a financial crisis, the injection of liquidity is bound to be more indiscriminate. Both firms deserving to survive, and those not so deserving, obtain a lifeline from the sea of money that central banks usher into the financial system.

It bears reiterating that Spencer's market solution requires that interest rates be allowed to rise during periods of financial stress. Not only does this preclude the further misallocation of capital, by thwarting "speculators from making further engagements", the increase in interest rates is what provides the incentive for banks and other suppliers of credit in the financial markets to offer loans to liquidity starved companies with collateral to pledge (Ibid., p. 346). 
Whether this would be a politically palatable strategy to adopt, Spencer does not say. It is clearly not the approach taken nowadays by central banks. He evidently expects that politicians will be able to withstand the opposition that would be sparked if interest rates were allowed to rise during a period of widespread financial difficulty. Spencer's expectation reflects a political context in which the vote was restricted to propertied males consisting of less than $10 \%$ of the British population (The National Archives 2019). Yet one may justly wonder whether higher interest rates could be sustained even in such a limited democratic context. Spencer himself noted the tendency of policymakers and the public during his time to look to the government for security. Among all the objections one might raise against Spencer's market solution, the political obstacles to its implementation looms as the biggest.

\section{ENCOURAGING SOUND FINANCIAL INSTITUTIONS}

Another serious objection that could be leveled at Spencer is that it is not enough to explain how a proposed financial architecture can stand up against economics shocks. It is also important, if perhaps not more so, that the proposed architecture not be predisposed to generating problems in the first place. Though it might be helpful to understand how market forces can resolve financial crises, it would only be worth relying on those forces if they did not precipitate such crises. Yet if private banks are free to issue promises to pay as they wish, will they not create excess money? After all, private banks seek to maximize their profits, which comes from the added interest revenues in offering more loans. Will this lending not artificially inflate the economy, kindling a boom that inevitably ends in a bust? Surely, the objector will say, this dynamic will subject the financial system to recurring disturbances. 
As previously mentioned, supporters of free banking had tended to orient their cases around the claim that their scheme would discourage crises from ever occurring. Not surprisingly, this is the part of Spencer's analysis that most closely mirrors the arguments of other free bankers. Accordingly, Spencer asks: "Shall the merchant, the manufacturer, or the shopkeeper, be allowed so to invest his capital as to risk the fulfillment of his engagements?" (p. 343) If the government has no place telling an automobile company how many cars it should make or a clothing retailer how many pants and dresses to stock on its shelves, the same logic holds for banks when they choose how to lend money. To believe otherwise, Spencer says, is to "think that the banker acquired, in virtue of his occupation, some abnormal desire to ruin himself' (p. 344). Considerations of prudence can be expected to influence decision making in banking just as it does in other industries where the specter of losses and, ultimately, bankruptcy looms as the price of bad choices. Among financial institutions, this threat is represented by the bank run, in which the creditors of the bank, chiefly depositors, opt en masse to withdraw their money at the same time. Alternatively, where convertibility is promised, a bank run occurs when a sizable contingent of the bank's creditors simultaneously request the exchange of its notes for species. Spencer holds that banks have more than enough incentives to take measures to avoid runs. They can be trusted to maintain high capital adequacy ratios, preserve ample cash reserves, and exercise caution in their lending. As Spencer sees it, "a banker will not, on the average of cases, issue more notes than in his judgement it is safe to issue ; seeing that if his promises-to-pay in circulation, are much in excess of his available means of paying them, he runs a great risk of having to stop payment - a result of which he has no less horror than other men [emphasis his]" (p. 344) Spencer concedes that this conduct cannot be guaranteed to happen in every financial institution. But no amount of laws or 
regulations can prevent all instances of human folly. So long as the costs of poor decision making are kept in place, we can expect probity to generally prevail.

Rather than the banks being motivated to lend lavishly, Spencer figures that they will endeavor to burnish their reputations. In a free banking framework, each firm would have to convince people to accept their notes and deposit money with them. The notes and deposits would have to be convertible into something whose value is independent of the bank's viability and capacity to keep its promises. This object could not be a central bank's notes or deposits, since free banking precludes any organization being granted a monopoly by government. The object of the bank's various promises to pay would have to be species. Given how money has historically developed independently of central banks, this species would consist of precious metals, primarily gold. In seeking to build reputational capital, therefore, the banks would be compelled to back their money issuance with gold. Furthermore, they will endeavor to cultivate an image of safety through a track record of steady profits, while avoiding even the appearance of a misstep. Indeed, Spencer suggests that the concern for reputation might lead banks to allow large depositors to regularly examine their books (pp. 353-354). These parties, having the incentive to uncover any irregularities, can keep the bank accountable and provide confidence to the general run of its depositors. Instead of a race to the bottom by way of speculative gambles, Spencer reckons that free banking will be a race to the top by way of reputational investments.

For this positive condition to be realized, governments do need to enforce the convertibility pledge through the courts. According to Spencer, governments must desist from relaxing that requirement through legislation or its execution of policy. Bailouts of any kind, whether through the abrogation of convertibility or injections of capital into banks, must be 
entirely ruled out. Even the mere possibility of a government rescue will change the calculus of bank executives and incline them towards more speculative financings than prudence would otherwise dictate. The thought of bankruptcy must always be crossing bankers' minds. Governments that dim such thoughts will bring about the very financial havoc they seek to avoid, a point that Spencer underlines by alluding to bank failures that plagued the United States during the first half of the nineteenth century. He saw these as the natural outcome of U.S. state governments suspending the convertibility of notes whenever the banks ran into difficulty. "The ultimate result of shielding men from the effects of folly", Spencer pronounces, "is to fill the world with fools" (p. 354).

As was the case with the government's meddling in interest rates during a financial crisis, one is left wondering here whether there is a political imperative giving rise to bailouts that Spencer is underestimating. To be sure, one could interpret that imperative as the influence of the financial industry over politicians. Both to protect jobs of constituents with stakes in that industry, and to maintain the flow of campaign donations, politicians do have motives to come to the assistance of banks. Yet it can also be argued that finance is an interconnected arena in a way that other industries like manufacturing and retailing are not. The assets of Amazon are not impaired when Sears fails, whereas the same cannot be said among banks for which the assets of one are often the liabilities of another. Hence, the failure of one bank is liable to spread trouble to other banks, however prudent the latter may have operated. Preventing this contagion by giving a lifeline to any especially interconnected bank could be viewed as a legitimate response by the government in its oversight of the public interest. This is something that Spencer does not address. In fairness, however, one might defend him by arguing that the 
problem of negative network effects would be forestalled in a free banking regime by the incentives that would exist for financial institutions to erect large capital buffers.

\section{CONCLUSION}

As part of his grand philosophical project to synthesize the human sciences, Herbert Spencer addressed the subjects of money and banking, doing so from both a moral and economic point of view. His moral analysis proceeded from an evolutionary theory of ethics, according to which justice entails the principle of equal freedom, whereby each individual should be at liberty to act as they wish, subject to the limits imposed by the same liberty belonging to others. From this principle, Spencer infers the inadmissibility of any government regulated system of finance. Instead, he holds that that the principle of equal freedom entails a financial architecture in which everyone is free to run a bank and issue monetary instruments at the same time as individuals and companies are permitted to transact with any bank that they deem suitable. In other words, justice demands free banking. On economic grounds, Spencer further defended this conclusion by arguing that the banking industry is self-regulating in its management of the money supply. Business needs will usually dictate the level of the money supply, including the proportion therein between immediate and future forms of payment. Even during crises, the acid test for any financial system, banks left alone by the government can be expected to provide much needed liquidity, so long as interest rates are permitted to rise when money initially becomes scarce. Nor should we fear, Spencer thinks, that unregulated banks will stoke unsustainable booms through excessive lending and money creation. Like other businesses, the threat of failure provides banks with incentives against the overproduction of their goods and services. It is the proper, and indeed sole, role of government to maintain the 
credibility of this bankruptcy threat through its enforcement of the contracts that banks have negotiated with their customers.

Spencer's case for free banking is admittedly not immune to reasonable criticism. The moral part of his case can be questioned for the deductive approach he adopts. Money and banking may well be matters that are too complex and contingent upon circumstances to be settled by a logical proof. And once the contingencies of money and banking are taken into account, the political realities impinging on the realm of finance need to be considered in any assessment of Spencer's vision. Especially noteworthy in this regard are the political constraints posed in a democratic society against the market cure of higher interest rates for a crisis, not to mention the policy of doing nothing against the contagion potential of interconnected banks. Still, these may well not be irredeemable flaws in what is, all things considered, a forceful and insightful analysis. 


\section{REFERENCES}

Bagehot, Walter. 1873. Lombard Street: A Description of the Money Market. New York: Scribner, Armstrong, and Company

Bosanquet, Charles. 1810. Practical Observations on the Report of the Bullion Committee. London: Galabin and Marchand

Boyd, William. 1811. A Letter to the Right Honourable William Pitt on the Influence of the Stoppage of Issues in Specie at the Bank of England on the Prices of Provisions and Other Commodities. London: James Ridgway

Cornett, Marcia, Jamie Millon, John McNutt, Philip E. Strahan and Hassan Tehranian. 2011. "Liquidity risk management and credit supply in the financial crisis." Journal of Financial Economics 101 (2): 297-312.

Dawkins, Richard. 1976. The Selfish Gene. Oxford: Oxford University Press

European Central Bank, 2018. "Monetary Aggregates".

https://www.ecb.europa.eu/stats/money_credit banking/monetary aggregates/html/index.en.ht $\underline{\mathrm{ml}}$. Accessed December 29, 2018

Federal Reserve System. 2018. "What is the Money Supply? Is It Important?" https://www.federalreserve.gov/faqs/money_12845.htm Accessed December 29, 2018

Fetter, Frank W. 1959. “The Politics of the Bullion Report”, Economica 26 (102): 99-120

Francis, Mark. 2007. Herbert Spencer and the Invention of Modern Life. Ithaca, NY: Cornell University Press

Friedman, Milton and Anna J. Schwartz. 1963. A Monetary History of the United States 18671960. Princeton: Princeton University Press.

Fukuyama, Francis. 1995. Trust: The Social Virtues and The Creation of Prosperity. New York, Free Press.

Hauser, Marc D. 2006. Moral Minds: How Nature Designed Our Universal Sense of Right and Wrong. New York: Harper Collins

Hofstadter, Richard. 1955. Social Darwinism in American Thought. Boston: Beacon Press.

Kennedy, James G. 1978. Herbert Spencer. Boston: Twayne Publishers

Kinnear, John. G. 1847. The Crisis and the Currency with a Comparison of the English and Scotch Systems of Banking. London: John Murray, Albemarle Street 
Laidler, David. 2000. "Highlights of the Bullionist Controversy", EconStor 2000 (02). https://www.econstor.eu/bitstream/10419/70368/1/332954749.pdf . Accessed December 29, 2018

Leonard, Thomas C. "Origins of the myth of social Darwinism: The ambiguous legacy of Richard Hofstadter's Social Darwinism in American Thought." Journal of Economic Behavior \& Organization 71, no. 1 (2009): 37-51.

Mingardi, Alberto. Herbert Spencer. New York: Continuum

Mints, Lloyd W. 1945. A History of Banking Theory in Great Britain and the United States. Chicago: University of Chicago Press.

Offer, John. 2010. Herbert Spencer and Social Theory. New York: Palgrave Macmillan Pinker, Steven. 2002. Blank Slate: The Modern Denial of Human Nature. New York: Penguin Ridley, Matt. 1996. The Origins of Virtue. London: Penguin

Rothbard, Murray. [1995] 2006. Classical Economics: An Austrian Perspective on the History of Economic Thought, Vol. 2. Auburn: Ludwig von Mises Institute.

Rothbard, Murray. 1988. "The Myth of Free banking in Scotland." The Review of Austrian Economics 2 (1): 229-245.

Smith, Vera. 1990 [1936]. The Rationale of Central Banking and the Free Banking Alternative. Indianapolis: Liberty Fund

Spencer, Herbert. 1851. Social Statics: Or The Conditions Essential to Human Happiness Specified and The First of Them Developed. London: John Chapman

Spencer, Herbert. 1868. Essays: Scientific, Political, and Speculative. London: Williams and Norgate.

Spencer, Herbert. 1893. The Principles of Ethics, Vol. 2. New York: D. Appleton and Company Spencer, Herbert. 1895. The Principles of Ethics, Vol. 1. New York: D. Appleton and Company Spencer, H. (1898). The Principles of Psychology, Vol. II-2. New York: D. Appleton and Company.

Spencer, Herbert. 1996 [1891]. "State Tamperings with Money and Banks”. In Herbert Spencer: Collected Writings, Vol. 11. London: Routledge/Thoemmes Press 
Taylor, M.W. (2007). The Philosophy of Herbert Spencer. London: Continuum.

The National Archives. 2019. "The Struggle for Democracy".

http://www.nationalarchives.gov.uk/pathways/citizenship/struggle democracy/getting vote.ht m. Accessed September 21, 2019

Victoriae Reginae. 1892 [1844]. "An Act to Regulate the Issue of Bank Notes, and for Giving to the Governor and Company of the Bank of England certain Privileges for a Limited Period". London: Eyre and Spottiswoode.

http://www.legislation.gov.uk/ukpga/1844/32/pdfs/ukpga_18440032_en.pdf?view=extent Accessed September 21, 2019

Viner, Jacob. 1937. Studies in the Theory of International Trade. New York: Harper and Brothers

White, Lawrence. 1984. Cambridge, U.K.: Cambridge University Press

Wilson, James. 1847. Capital, Currency, and Banking. London: The Economist

Wright, Robert. 1994. The Moral Animal: Why We Are, the Way We Are. New York: Pantheon 